\title{
Hvordan indsættes DOI-navnet korrekt i en litteraturliste?
}

Det findes forskellige standarder man kan følge ved udarbejdelsen af en litteraturliste. Disse kaldes for output styles. For at et tidsskrift kan få tildelt en DOI er det vigtigt at forfatterne overholder de krav til udfærdigelse af en litteraturliste, der opstilles af DOI-udbyderen CrossRef. Kravet er, at en reference indskrives med DOI, såfremt det har et sådant. Fælles for alle de mest udbredte output styles - APA 6th Edition, Chicago 16th Edition, Harvard, MLA 7th Edition,Turabian 8th Edition og Vancouver - gælder den regel, at DOI-navnet altid indsættes til slut i referencen. For de artikler, der både har et DOI og en URL anbefales det kun at anvende DOI. Har artiklen endnu ikke en DOI indsættes fortsat en URL, hvis den forefindes.

Nedenfor vises eksempler på en litteraturliste som den tager sig ud i overensstemmelse med de nævnte output styles.

\section{APA $6^{\text {th }}$ Edition}

Baer, M. D. (2015). Muslim Encounters with Nazism and the Holocaust: The Ahmadi of Berlin and Jewish Convert to Islam Hugo Marcus. The American Historical Review, 120(1), 140-171. http://dx.doi.org/doi:10.1093/ahr/120.1.140

Murphy, N. (2015). Henry VIII's First Invasion of France: The Gascon Expedition of 1512. The English Historical Review, 130(542), 25-56. http://dx.doi.org/doi:10.1093/ehr/ceu367

Stelzel, P. (2015). Transnationalism and the History of Historiography: A Transatlantic Perspective. History Compass, 13(2), 78-87. http://dx.doi.org/doi:10.1111/hic3.12218

\section{Chicago $16^{\text {th }}$ Edition}

Baer, Marc David. 2015. "Muslim Encounters with Nazism and the Holocaust: The Ahmadi of Berlin and Jewish Convert to Islam Hugo Marcus." The American Historical Review 120 (1): 140-171. http://dx.doi.org/doi:10.1093/ahr/120.1.140

Murphy, Neil. 2015. "Henry VIII's First Invasion of France: The Gascon Expedition of 1512." The English Historical Review 130 (542): 25-56. http://dx.doi.org/doi:10.1093/ehr/ceu367

Stelzel, Philipp. 2015. "Transnationalism and the History of Historiography: A Transatlantic Perspective." History Compass 13 (2): 78-87. http://dx.doi.org/doi:10.1111/hic3.12218 


\section{Harvard}

Baer, M.D. 2015, "Muslim Encounters with Nazism and the Holocaust: The Ahmadi of Berlin and Jewish Convert to Islam Hugo Marcus", The American Historical Review, vol. 120, no. 1, pp. 140-171. http://dx.doi.org/doi:10.1093/ahr/120.1.140

Murphy, N. 2015, "Henry VIII's First Invasion of France: The Gascon Expedition of 1512", The English Historical Review, vol. 130, no. 542, pp. 25-56. http://dx.doi.org/doi:10.1093/ehr/ceu367

Stelzel, P. 2015, "Transnationalism and the History of Historiography: A Transatlantic Perspective", History Compass, vol. 13, no. 2, pp. 78-87. http://dx.doi.org/doi:10.1111/hic3.12218

\section{MLA $7^{\text {th }}$ Edition}

Baer, Marc David. "Muslim Encounters with Nazism and the Holocaust: The Ahmadi of Berlin and Jewish Convert to Islam Hugo Marcus." The American Historical Review 120.1 (2015): 140-71. http://dx.doi.org/doi:10.1093/ahr/120.1.140

Murphy, Neil. "Henry VIII's First Invasion of France: The Gascon Expedition of 1512." The English Historical Review 130.542 (2015): 25-56. http://dx.doi.org/doi:10.1093/ehr/ceu367

Stelzel, Philipp. "Transnationalism and the History of Historiography: A Transatlantic Perspective." History Compass 13.2 (2015): 78-87. http://dx.doi.org/doi:10.1111/hic3.12218

\section{Turabian $8^{\text {th }}$ Edition}

Baer, Marc David. 2015. "Muslim Encounters with Nazism and the Holocaust: The Ahmadi of Berlin and Jewish Convert to Islam Hugo Marcus.". The American Historical Review 120, no. 1: 140-171. http://dx.doi.org/doi:10.1093/ahr/120.1.140

Murphy, Neil. 2015. "Henry VIII's First Invasion of France: The Gascon Expedition of 1512.". The English Historical Review 130, no. 542: 25-56. http://dx.doi.org/doi:10.1093/ehr/ceu367

Stelzel, Philipp. 2015. "Transnationalism and the History of Historiography: A Transatlantic Perspective.". History Compass 13, no. 2: 78-87. http://dx.doi.org/doi:10.1111/hic3.12218 


\section{Vancouver}

(1) Baer MD. Muslim Encounters with Nazism and the Holocaust: The Ahmadi of Berlin and Jewish Convert to Islam Hugo Marcus. The American Historical Review 2015 February 01;120(1):140-171.

http://dx.doi.org/doi:10.1093/ahr/120.1.140

(2) Murphy N. Henry VIII's First Invasion of France: The Gascon Expedition of 1512. The English Historical Review 2015 February 01;130(542):25-56. http://dx.doi.org/doi:10.1093/ehr/ceu367

(3) Stelzel P. Transnationalism and the History of Historiography: A Transatlantic Perspective. History Compass 2015;13(2):78-87. http://dx.doi.org/doi:10.1111/hic3.12218

Niels Erik Frederiksen og Jesper Boserup Thestrup, marts 2015 